Brewerton, D. A., et al. (1973 b). Lancet, 2, 996
Brewerton, D. A., et al. (1973 c). Lancet, 2, 994.

Caffrey, M. F. P., and James, D. C. O. (1973). Nature, 242, 121

Dausett, J., and Colombani, J. (editors) (1973). Histocompatibility Testing 1972. Copenhagen, Munksgaard.

Gelsthorpe, K., and Doughty, R. W. (1973). Tissue Antigens, 3, 316.

International Union against Cancer (U.I.C.C.) (1970). Chest, 58, 57.

Kissmeyer-Nielsen, F., and Kjerbye, K. E. (1967). In Histocompatibility Testing 1967, ed. E. S. Curtoni, P. L. Mattiuz, R. M. Tosi, p. 381 Copenhagen, Munksgaard.
Lippman, M., et al. (1973). Annals of Internal Medicine, 79, 807.

Pernis, B., Vigliani, E. G., and Selikoff, I. J. (1965). Annals of New York Academy of Science, 132, 112 .

Rossiter, C. E. (1972). Transactions of the Society of Occupational Medicine, $22,83$.

Schlosstein, L., et al. (1973). New England fournal of Medicine, 288, 704.

Soutar, C. A., Turner-Warwick, M., and Parkes, W. R. (1974). British Medical fournal, 3, 145.

Turner-Warwick, M., and Parkes, W. R. (1970). British Medical Fournal, 3,492 .

\title{
Alopecia Areata, Autoimmunity, and Down's Syndrome
}

\author{
ANTHONY DU VIVIER, DOWLING D. MUNRO
}

British Medical fournal, 1975, 1, 191-192

One-thousand control subjects ( 543 male, 457 female) were examined at three of these hospitals. They were suffering from mental retardation caused other than by Down's syndrome. Their average age was 40 years.

The hair of the scalp, beard area, and eyebrows of all the patients was personally examined and a diagnosis of alopecia areata was made on clinical grounds. The covered hair-bearing areas of the body were not examined unless alopecia areata was found on the scalp or face. A sample of blood was taken from the patients with alopecia areata. The haemoglobin total and differential white cell count were estimated and the blood was tested for fluorescent antibodies against nuclei, mitochondria, thyroid epithelium, and colloid and gastric parietal cells. The antithyroglobulin antibody titre, using the tanned red cell agglutination test, and the antimicrosomal antibody titre, using the complement fixation test, were also estimated. were examined for the presence of fluorescent autoantibodies. Antibodies against thyroid components tended to be present in female mongols with alopecia areata in comparison with females in a normal population but not in male mongols. Furthermore, eight out of 23 female mongols $(35 \%)$ with alopecia areata had antibodies against thyroid components compared with two out of 23 female mongols $(9 \%)$ without alopecia areata.

\section{Introduction}

Clinically we have thought that alopecia areata is unusually common in Down's syndrome. Standard works on dermatology (Fitzpatrick et al., 1971; Rook et al., 1972), however, do not mention this association and so we set out to examine the possibility that it exists.

Alopecia areata is thought to be an autoimmune disorder since it is associated with pernicious anaemia, vitiligo, autoimmune adrenal insufficiency, and Hashimoto's thyroiditis (Cunliffe et al., 1969); histologically with lymphocytic infiltrate; and therapeutically the disease responds to steroids. Thus we investigated mongols found to have alopecia areata for antibodies to thyroid epithelium and colloid, DNA, and gastric parietal cells.

\section{Patients and Methods}

We visited eight hospitals for the mentally subnormal near London and examined 1000 patients clinically diagnosed as mongols. We did not record whether their condition was the result of trisomy 21, mosaicism, or translocation because the karyotypes had not been studied in every case. Their ages ranged from 5 to 67 years; 560 were male (average age 30 years) and 440 female (average age 33 years).

Department of Dermatology, St. Bartholomew's Hospital, London EC1A 7BE and Edgware General Hospital, Middx.

\section{Results}

Sixty cases of alopecia areata were found among the 1000 mongols $(6 \%), 23$ in females and 37 in males. In 25 of these cases the condition had progressed to alopecia totalis or universalis. Only one of the 1000 subnormal controls $(0.1 \%)$ had alopecia areata, and no fluorescent antibodies were detected in her serum. Of the 60 mongols with alopecia areata $14(23 \%)$ were positive for fluorescent antibodies. Ten of these were female patients, of whom eight were positive for thyroid antibodies, one was positive for antinuclear factor, and one was positive for gastric parietal cell antibodies. In the four male patients the tests gave only weakly positive results. One had gastric parietal cell antibodies and the other three thyroid antibodies. These numbers in the male patients were no greater than might be expected by chance.

Since eight of the 23 female mongols (35\%) with alopecia areata had thyroid antibodies 23 age-matched female mongols without alopecia areata were investigated. Two patients $(9 \%)$ had antinuclear antibodies and two had thyroid antibodies.

\section{Discussion}

Possibly the prevalence of alopecia areata was a little higher than $6 \%$ since cases confined to the covered hair-bearing areas of the body may have been missed. The high proportion of 25 cases of alopecia totalis and universalis among the 60 alopecia patients is remarkable. Trichotillomania or other hair-loss conditions did not present any problem in the differential diagnosis in these patients.

Muller and Winkelmann (1963) found an increased prevalence of thyroid disease in alopecia areata: of 736 patients with alopecia areata they found that $8 \%$ had thyroid disease, $4 \%$ vitiligo, and $2 \%$ diabetes mellitus. Cunliffe et al. (1968) found thyroid disease associated with vitiligo and showed raised thyroglobulin antibody titres in this condition; moreover, alopecia areata occurred in $18 \%$ of their patients. Cunliffe et al. 
(1969) also studied alopecia areata and thyroid disease and confirmed Muller and Winkelmann's findings but were unable to show an increased prevalence of thyroglobulin antibody in comparison to Dingle et al. (1966) in a survey of a general practice population in northern England.

On the other hand, Kern et al. (1973) looked for additional evidence of autoimmunity in 40 cases of alopecia areata and showed a significantly raised prevalence of antibodies against thyroglobulin, parietal cells, adrenal cells, and thyroid cells. They could not, however, find antibodies against cells of hair follicles. Munro and Chanarin (1974) have confirmed an increased prevalence of intrinsic factor and parietal cell antibodies in female patients with alopecia areata compared with a control group.

Benda (1949) noted a history of thyroid disease in $38.5 \%$ of mothers of mongols. Other workers (Kurland et al., 1957; Coppen and Cowie, 1960; Hayles et al., 1965; Fialkow, 1966) have confirmed this and shown mongols themselves to be particularly susceptible to thyroid disease. Recently thyroid antibodies have been shown to be unusually common in mongols and their relatives (Mellon et al., 1963; Fialkow et al., 1965; Saxena and Pryles, 1965; Burgio et al., 1966; Dallaire and Flynn, 1967; Vanhaelst et al., 1970). Similar findings occur in two other chromosomal abnormalities-namely, Klinefelter and Turner's syndromes (Sparkes and Motulsky, 1963; Williams et al., 1964).

In our series $8(35 \%)$ of the female mongols with alopecia areata had thyroid antibodies compared with only $2(9 \%)$ of a group of age-matched female mongols without alopecia areata. Fialkow (1970) found that 34\% of 106 mongols in an institution had thyroid antibodies. He did not specify whether any of them had alopecia areata. Jacobs et al. (1969) measured antibodies to thyroid cytoplasm, parietal cells, and intrinsic factor in a randomly selected normal population in Wales. They found thyroid antibodies in $12.2 \%$ of the female subjects under the age of 55 and in $17.8 \%$ of those over this age. Doniach et al. (1963), in a survey of 100 normal female subjects selected at random, found antibodies in $13 \%$. Our findings in female mongols with alopecia areata differ significantly $(P<0.01)$ from both those series, whereas the results in the female mongols without alopecia areata do not.
Mongolism is a chromosomal disorder and yet thyroid autoantibodies are often found in the condition. Alopecia areata occurs commonly in autoimmune disorders. We have shown that alopecia areata occurs more frequently in mongols than would be expected by chance, which suggests that there is a link between autoimmunity and chromosomal abnormalities.

We thank the medical staff, nursing staff, and patients of Harperbury, Leavesden, South Ockendon, Manor, Botleys Park, Leybourne Grange, Cell Barnes, St. Lawrence's, and Leytonstone House hospitals for their co-operation in this survey. We also thank the Immunodiagnosis Laboratory, St. Bartholomew's Hospital, London, for the immunofluorescence work.

Requests for reprints should be sent to Dr. D. D. Munro.

\section{References}

Benda, C. E. (1949). Fournal of the American Medical Association, 139, 979. Burgio, G. R., et al. (1966). Lancet, 1, 497.

Coppen, A., and Cowie, V. (1960). British Medical fournal, 1, 1843.

Cunliffe, W. J., et al. (1968). British fournal of Dermatology, 80, 135.

Cunliffe, W. J., et al. (1969). British fournal of Dermatology, 81, 879.

Dallaire, L., and Flynn, D. (1967). Canadian Medical Association fournal, 97,209 . Dingle, P. R., et al. (1966). Clinical and Experimental Immunology, 1, 277.
Doniach, D., Roitt, I. M., and Taylor, K. B. (1963). British Medical fournal, 1,1374 .

Fialkow, P. J. (1966). American fournal of Human Genetics, 18, 93.

Fialkow, P. J. (1970). Annals of the New York Academy of Sciences, 171, 500. Fialkow, P. J., et. al. (1965). Lancet, 2, 868.

Fitzpatrick, T. B., et al. (1971). Dermatology in General Medicine. New York, McGraw-Hill.

Hayles, A. B., Hinrichs, W. L., and Tauxe, W. N. (1965). Pediatrics, 36, 608. Jacobs, A., et al. (1969). British fournal of Haematology, 17, 589.

Kern, F., et al. (1973). Archives of Dermatology, 107, 407.

Kurland, G. S., et al. (1957). Fournal of Clinical Endocrinology, 17, 552.

Mellon, J. P., Pay, B. Y., and Green, D. M. (1963). Fournal of Mental Deficiency Research, 7, 31.

Muller, S. A., and Winkelmann, R. K. (1963). Archives of Dermatology, 88, 290.

Munro D. D and Chanarin, I. (1974). To be published.

Munro, D. D., and Chanarin, I. (1974). To be published. of Dermatology. Oxford, Blackwell Scientific.

Saxena, K. M., and Pryles, C. V. (1965). Fournal of Pediatrics, 67, 363.

Sparkes, R. S., and Motulsky, A. G. (1963). Lancet, 1, 947.

Vanhaelst, L., et al. (1970). Fournal of Clinical Endocrinology and Metabolism,

30, 792.
Williams, E. D., Engel, E., and Forbes, A. P. (1964). New England fournal of Medicine, 270, 805.

\section{MEDICAL MEMORANDA}

\section{Herpes Simplex Virus and Guillain-Barré Polyradiculitis}

\section{BENT DE FINE OLIVARIUS, MORTEN BUHL}

\author{
British Medical fournal, 1975, 1, 192-193
}

Herpes simplex virus (H.S.V.) is a well known aetiological agent in various disorders of neurological interest-for example, acute necrotizing encephalitis, which is often fatal (Overgaard et al., 1971; Johnson et al., 1972), and encephalitis with a more benign course (Buhl, 1974). Mild aseptic meningitis may in some cases be caused by an infection with H.S.V. type 2 , in which case it is related to genital herpes infections (Terni et al., 1971; Nahmias and Roizman, 1973).

\footnotetext{
University Department of Neurology, Kommunehospitalet, 8000 Aarhus C, Denmark

BENT DE FINE OLIVARIUS, M.D., Professor of Neurology

MORTEN BUHL, M.D., Clinical Assistant in Neurology
}

In Guillain-Barré polyradiculitis no single aetiological agent has been found though the disorder has been shown to be associated with several herpesvirus infections-namely, herpes zoster (Dayan et al., 1972), Epstein-Barr virus infection (Grose and Feorino, 1972), and cytomegalovirus infection (Klemola et al., 1967).

H.S.V., however, is rarely associated with radicular disorders of the nervous system and we have been able to find only one verified case of polyradiculitis in the literature in which H.S.V. infection preceded the acute neurological symptoms (Melnick and Flewett, 1964). We have had the opportunity of observing a further case in which such a correlation seems to have occurred.

\section{Case Report}

The patient, a 62-year-old woman, had no family history of neurological or other diseases. As a child and at the age of $\mathbf{4 0}$ she was treated in hospital for respiratory difficulties and bronchitis. She had never had shingles or ulcers in or near the mouth, nose, or genitals.

The present illness started on 6 November 1973 with exhaustion, universal dedolations of the muscles, and slight headache, and for two days she had a fever reaching $39^{\circ} \mathrm{C}$. A few days previously she had been in close contact with a grandchild who had "coldsores" around the nose. All her symptoms disappeared on 8 November. 